\title{
Palaeosecular variation for 0.1-21 Ka from the Okataina Volcanic Centre, New Zealand
}

\author{
Hidefumi Tanaka $^{1}$, Naoyuki Komuro ${ }^{1 *}$, and Gillian M. Turner ${ }^{2}$ \\ ${ }^{1}$ Faculty of Education, Kochi University, Kochi 780-8520, Japan \\ ${ }^{2}$ School of Chemical and Physical Sciences, Victoria University of Wellington, Wellington, New Zealand \\ (Received September 27, 2007; Revised March 25, 2008; Accepted March 30, 2008; Online published January 23, 2009)
}

\begin{abstract}
Studies of palaeodirections and palaeointensities were carried out on mainly rhyolitic lavas and pyroclastics from the Okataina Volcanic Centre, New Zealand, which has erupted during the past 32 kyr. Of the 17 sites studied, 14, spanning the period 0.1-21 Ka yielded good mean palaeodirections, while three carried unstable natural remanent magnetizations. Of 49 specimens from 7 sites, on which Thellier palaeointensity experiments were carried out, 21 specimens gave successful results, yielding 3 site mean palaeointensities for $1886 \mathrm{AD}$, $5 \mathrm{Ka}$, and 7.5 Ka. When the new palaeodirections, together with previously reported archaeo and volcanic data, were compared with sedimentary records from New Zealand and eastern Australia for the last 10 kyr, good agreement was obtained in inclination but discrepancies were observed in declination. The new $7.5 \mathrm{Ka}$ and $5 \mathrm{Ka}$ palaeointensities are moderately high and relatively low, respectively, and are concordant with the global trend. The mean palaeointensity obtained for $1886 \mathrm{AD}$ is, 11\% higher than the IGRF1900. The difference is scarcely significant, but might indicate a small bias toward high values. Although the sedimentary directional curves show excellent agreement with the prediction from CALS7K, the fit of the palaeointensity data to model values was relatively poor over the wider Pacific region. Further reliable palaeointensity data are needed to solve the discrepancy.
\end{abstract}

Key words: Palaeosecular variation, Okataina, rhyolite lava, palaeointensity, Thellier method.

\section{Introduction}

Palaeomagnetic studies of archaeological artifacts, volcanic rocks, and lake sediments have long contributed to the establishment of records of the geomagnetic secular variation that span the past 10-15 kyr. Much effort has been made to create datasets for various parts of the world (e.g., Kinoshita, 1970; Kovacheva, 1992; Sternberg et al., 1997) and further, to compile them into a global database (e.g., Creer et al., 1983; Daly and Le Goff, 1996). These data have often been used in the computation of low degree spherical harmonic global models (e.g., Ohno and Hamano, 1993; Hongre et al., 1998), and now a continuous global model to degree and order 10 , covering the last $7 \mathrm{kyr}$, CALS7K, is available (Korte and Constable, 2005) based on the most recent data compilation (Korte et al., 2005). Palaeointensity datasets have also been used to deduce millennium scale variations of virtual dipole moment (VDM) or virtual axial dipole moment (VADM) for the last 1012 kyr (e.g., McElhinny and Senanayake, 1982; Yang et al., 2000). Nevertheless, the data coverage in time and space is still sparse for the time range before $10 \mathrm{Ka}$ and for the area of the southern hemisphere. This study aims to contribute palaeodirections and intensities from the southern

\footnotetext{
*Now at Setsuyo Junior High School, Hirano-ku, Osaka 547-0033, Japan.

Copyright (c) The Society of Geomagnetism and Earth, Planetary and Space Sciences (SGEPSS); The Seismological Society of Japan; The Volcanological Society of Japan; The Geodetic Society of Japan; The Japanese Society for Planetary Sciences; TERRAPUB.
}

hemisphere for the last $20 \mathrm{kyr}$ from ${ }^{14} \mathrm{C}$ dated volcanic rocks in New Zealand.

\section{Samples}

Okataina Volcanic Centre (OVC) is one of eight rhyolitic eruptive centres in the Taupo Volcanic Zone, North Island, New Zealand. The most recent summary of its geology is given in Nairn (2002). The volcanic activity of the OVC started around 0.34 Ma and several caldera-forming eruptive episodes have occurred. The most recent voluminous caldera-forming eruptive episode was the $65 \mathrm{Ka}$ Rotoiti episode which was followed by the 45-28 Ka Mangaone pyroclastic eruptive episode. After $22 \mathrm{Ka}, 11$ distinctive intracaldera eruptive episodes followed, forming the present-day topographic features of Haroharo and Tarawera volcanic complexes.

The late Quaternary tephra formations of the North Island of New Zealand were comprehensively reviewed by Froggatt and Lowe (1990). These include distal airfall tephra and unconsolidated pyroclastics associated with each of the eruptive episodes of the Okataina Volcanic Centre. Froggatt and Lowe summarized and calculated weighted means, with standard errors, for numerous C-14 age estimates on each of the tephra. Nairn (2002) used these means, together with new C-14 age determinations on materials associated with proximal pyroclastic deposits, lava flows and domes to assign an "accepted age" at each eruptive episode as a whole. In most cases the ages of the proximal volcanic products are 100-200 years older than Froggatt and Lowe's 
Table 1. Site descriptions.

\begin{tabular}{|c|c|c|c|c|c|c|c|}
\hline Site & Deposit & $\begin{array}{l}\text { Eruptive } \\
\text { episode }\end{array}$ & $\begin{array}{l}\text { Age } \\
(\mathrm{Ka})\end{array}$ & $\begin{array}{c}\text { Tephra age } \\
\text { (yr BP) }\end{array}$ & $\begin{array}{l}\text { Lat } \\
\left({ }^{\circ} \mathrm{S}\right)\end{array}$ & $\begin{array}{l}\text { Lon } \\
\left({ }^{\circ} \mathrm{E}\right)\end{array}$ & Grid Ref. \\
\hline NK09 & Tarawera basalt dyke & $\begin{array}{l}\text { Tarawera } \\
\text { Basalt }\end{array}$ & $1886 \mathrm{AD}$ & & 38.218 & 176.523 & V16/186258 \\
\hline NK10 & Wahanga dome & Kaharoa & 0.7 & $770 \pm 20$ & 38.218 & 176.523 & V16/186258 \\
\hline NK16 & $\begin{array}{l}\text { Edgecumbe Avalanche } \\
\text { Breccia }\end{array}$ & & $2370 \pm 70$ yBP & & 38.095 & 176.725 & V16/368387 \\
\hline NK02 & Tapahoro lava flow & Whakatane & 5 & $4830 \pm 20$ & 38.164 & 176.519 & V16/182318 \\
\hline NK04 & Hainini Pyroclastics & Mamaku & 7.5 & $7250 \pm 20$ & 38.086 & 176.457 & V15/134407 \\
\hline NK05 & Hainini dome & Mamaku & 7.5 & $7250 \pm 20$ & 38.120 & 176.478 & V16/151368* \\
\hline NK06 & Waiti lava flow & Mamaku & 7.5 & $7250 \pm 20$ & 38.083 & 176.486 & V15/157411 \\
\hline NK18 & Matutu Pyroclastics & Rotoma & 9 & $8530 \pm 10$ & 38.037 & 176.561 & V15/227458 \\
\hline NK19 & Rotoma lava flow & Rotoma & 9 & $8530 \pm 10$ & 38.039 & 176.572 & V15/236455 \\
\hline NK01 & Pokohu lava flow & Waiohau & 11 & $11850 \pm 60$ & 38.165 & 176.519 & V16/185317 \\
\hline NK08 & Waikakareao lava flow & Waiohau & 11 & $11850 \pm 60$ & 38.208 & 176.542 & V16/203269 \\
\hline NK14 & Rotorua Pyroclastics & Rotorua & 13.5 & $13080 \pm 50$ & 38.210 & 176.366 & U16/048273 \\
\hline NK11 & Rotomahana dome & Rerewhakaaitu & 15 & $14700 \pm 110$ & 38.251 & 176.474 & V16/141224 \\
\hline NK07 & Hawea lava flow & Okareka & $18 \pm 3$ & & 38.183 & 176.570 & V16/228295 \\
\hline NK03 & Haumingi lava flow & Te Rere & 21 & $21100 \pm 320$ & 38.059 & 176.449 & V15/127436 \\
\hline NK15 & Te Koutu lava flow & Te Rere & 21 & $21100 \pm 320$ & 38.106 & 176.433 & V16/112386 \\
\hline NK17 & Mangaone Tephra & Mangaone & 32 & $27730 \pm 350$ & 38.092 & 176.730 & V16/372389 \\
\hline
\end{tabular}

Note:

Site is the site identification for palaeomagnetic study; Deposit is the flow name; Age is the best estimate of the eruptive episode as a whole by Nairn (2002), with possible uncertainties of \pm 100 years, while Tephra age is a weighted mean with a standard error of each tephra by Froggatt and Lowe (1990). Exceptions of the age are the Tarawera basalt dyke which age is historically known and the Edgecumbe Avalanche Breccia which has a single C-14 age; Lat, Lon, and Grid Ref. are latitude, longitude, and a grid reference of site locality, respectively; $(*)$, half of the core samples were taken at $200 \mathrm{~m}$ apart at $\left(38.119^{\circ} \mathrm{S}, 176.475^{\circ} \mathrm{E}, \mathrm{V} 16 / 149369\right)$.

ages for the corresponding tephra. This fact, together with field evidence suggests that each eruptive episode lasted up to a few hundred years, and so Nairn's accepted ages were given to the nearest 500 years, with possible uncertainties of \pm 100 years. In Table 1 we include Froggatt and Lowe's figures, which may be regarded as accurate and precise ages of the tephra, as well as Nairn's “accepted ages" for each eruptive episodes, which though accurate, represent less precise estimates of the age of any single eruptive product. The distribution of the volcanic products associated with OVC is shown in Fig. 1, which is simplified from figure 5 of Nairn (2002).

Palaeomagnetic samples were collected from lavas, pyroclastics, and domes at 17 sites whose descriptions are summarized in Table 1. All were formed during major eruptive episodes of the OVC except sites NK09, Tarawera basalt dyke, NK16, Edgecumbe Avalanche Breccia, and NK07, Hawea lava flow. Tarawera basalt dyke has a historical age of $1886 \mathrm{AD}$. The age of Edgecumbe Avalanche Breccia is based on a single ${ }^{14} \mathrm{C}$ age of $2370 \pm 70 \mathrm{yr}$ BP. The Hawea lava flow lies stratigraphically between the upper and lower eruptive episodes. The assigned age, $18 \mathrm{Ka}$, is the average age of the two episodes, while the error, $3 \mathrm{kyr}$, is half of their age difference. Site locations are included in Fig. 1 except for two sites (NK16, 17) which were collected at the foot of the Mt. Edgecumbe. Mt. Edgecumbe is an independent volcanic complex of Holocene age which lies about $10 \mathrm{~km}$ east of the region of Fig. 1.

Sites NK12 and NK13 are missing because they were collected from older volcanics. The former is the $0.28 \mathrm{Ma}$ old Matahina Ignimbrite, whose site mean direction was reported in Tanaka et al. (1996). The latter was an attempt to sample the $65 \mathrm{Ka}$ Rotoiti breccia, but it was found that the outcrop was not in situ.

A portable drill was used to collect 8-10 cores at each site. Each core was oriented using a magnetic compass and, when the sun was available, the solar azimuth was also recorded. Due to the generally weak magnetization of OVC rhyolitic rocks, the errors in the magnetically determined azimuths were quite small. The difference between the magnetic and the solar azimuths was usually less than $3^{\circ}$.

\section{Palaeodirections}

Two to four samples were selected from each site as pilot samples. Half of these were subjected to progressive alternating field demagnetization (AFD) and other half to progressive thermal demagnetization (THD). When determination of the characteristic remanence vectors was straightforward by both methods, AFD was applied to the remaining samples. In such cases demagnetization was stopped when it could be ascertained that the remanence vector decreased toward the origin of the orthogonal plot. However, for more than half of the samples, AFD with full steps up to $180 \mathrm{mT}$ or THD was necessary due to the presence of large secondary components or multiple remanence components.

Figure 2 shows examples of orthogonal plots of AFD and THD in which there is a single remanence component with no or only a small secondary component. Such samples with stable single components of remanence were found only in lava flows (NK01, 02, 03, 08, 15, 19), lava domes 


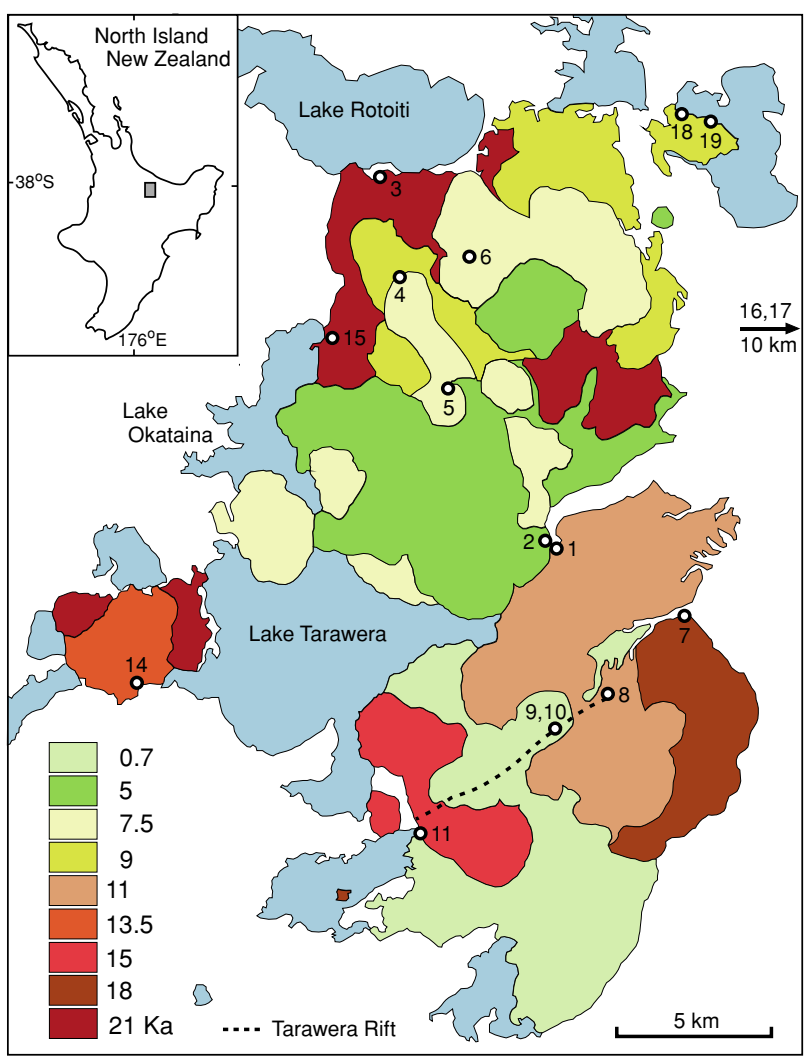

Fig. 1. Distribution of volcanic products from the Okataina Volcanic Centre, New Zealand. Open circles are site locations of palaeomagnetic samples. The map is simplified from figure 5 of Nairn (2002). The original color scheme has been modified in order to increase the clarity of the figure.

(NK10, 11), and a basalt dyke (NK09). For such units it was straightforward to calculate site mean palaeodirections, and the associated cones of $95 \%$ confidence $\left(\alpha_{95}\right)$ were small, generally less than 5 degrees.

Examples of more complicated remanences are shown in Fig. 3, in which orthogonal component plots of THD and AFD data are shown for specimens from a lava dome (NK05) and a lava flow (NK06), both of which are dated at $7.5 \mathrm{Ka}$. At the lava dome, samples were collected from two outcrops which are $200 \mathrm{~m}$ apart. The samples from the first outcrop carry two components of remanence which can be clearly separated only by THD, as shown in Fig. 3(a). The remanences of the samples from the second outcrop are basically single component with only a minor secondary component, as shown in Fig. 3(b). By taking only the remanence components that unblock below $540^{\circ} \mathrm{C}$ from the former, and taking the high coercivity components from the latter, the sample directions cluster closely, as shown in Fig. 3(e), readily defining a site mean palaeodirection. The presence of two remanence components in the first outcrop of NK05, which are separated only by THD, probably indicates some movement of the outcrop as the dome cooled through about $500^{\circ} \mathrm{C}$. The angle between the high- $T$ component and the site mean direction is $34^{\circ}$ which is observed mainly in inclination. The movement must have been very local because it was not recorded in the second outcrop which is only $200 \mathrm{~m}$ away. (a) NK01-7-B (lava, AFD)

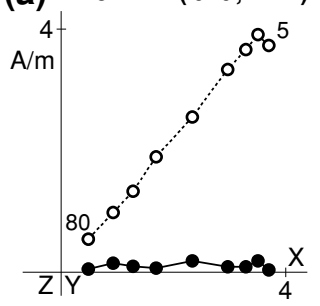

(b) NK19-1-2 (lava, THD)

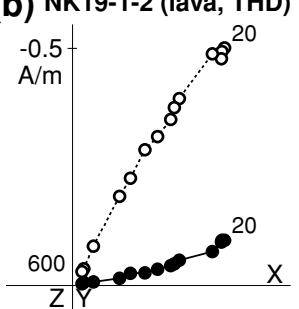

(c) NK10-8-3 (dome, AFD)

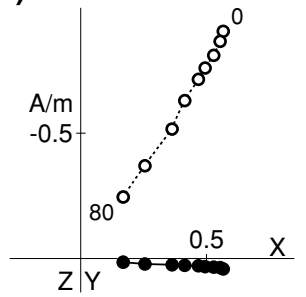

(d) NK11-1-3 (dome, THD)

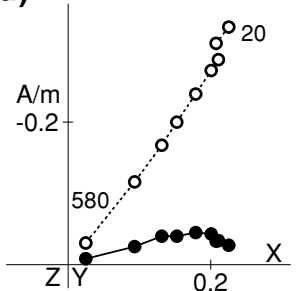

Fig. 2. Examples of progressive AFD and THD of remanent magnetizations in which there is a single component with little or no secondary component. (a) NK05-3-2 (THD)

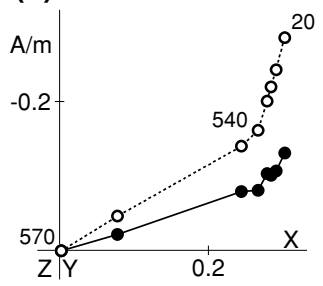

(c) NK06-7-C (THD)

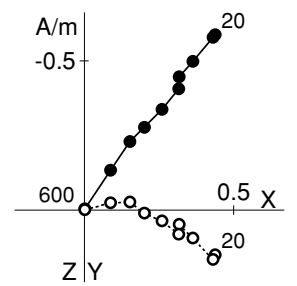

(e) NK05 (low-T) (b) NK05-10-3 (AFD)

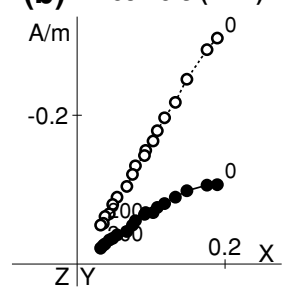

(d) NK06-4-3 (AFD)

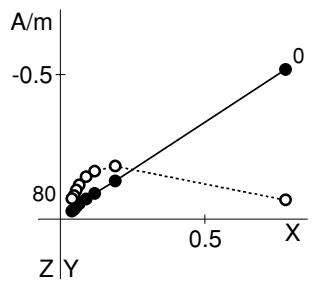

(f) NK06 (high-Hc)

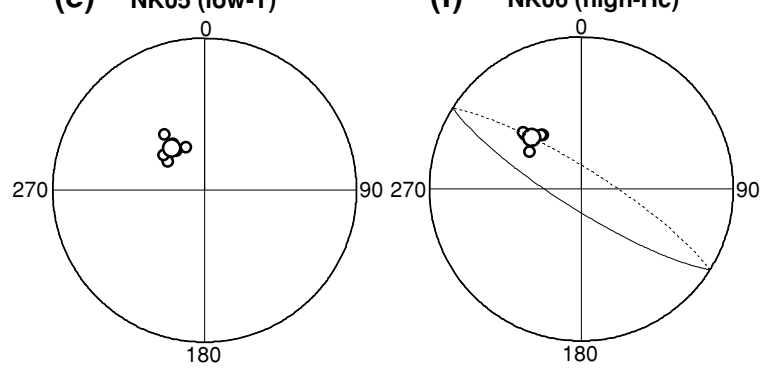

Fig. 3. Examples of orthogonal plot of AFD and THD of samples from Hainini lava dome $(a, b)$ and Waiti lava flow $(c, d)$ which both have ages of 7.5 Ka. Site mean directions for the Hainini lava dome (e) and the Waiti lava flow (f) reasonably agree with each other.

On the other hand, there were very large secondary components in the samples from the contemporary $7.5 \mathrm{Ka}$ lava flow (NK06) which was collected at the site location $4 \mathrm{~km}$ north of the dome site. The characteristic component was 
(a) NK16-3-3 (THD)

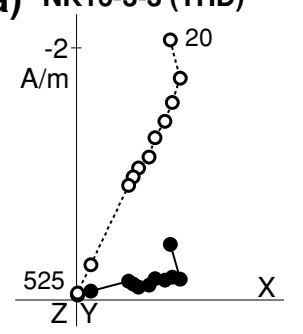

(c) NK04-3-2 (AFD)

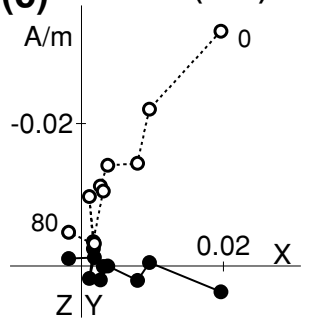

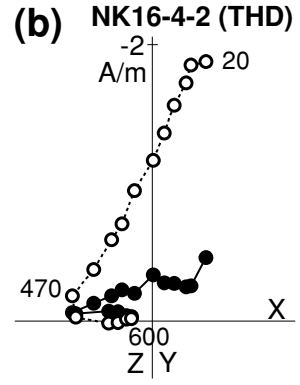

(d) NK17-6-1 (THD)

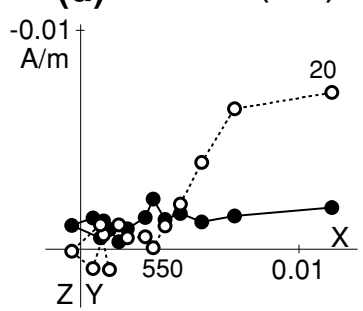

Fig. 4. Examples of orthogonal plots of THD from Edgecumbe avalanche breccia (a, b). A block rotation at $470^{\circ} \mathrm{C}$ is recognized in sample (b). Rejected examples are shown for samples from Hainini pyroclastics (c) and Mangaone tephra (d).

not well separated in THD as shown in the typical orthogonal plot of Fig. 3(c), but it was easier to define the high coercivity component by AFD as shown in Fig. 3(d). The large low blocking temperature or low coercivity component was interpreted as secondary because of the fact that the hysteresis parameters indicate the dominance of multidomain (MD) grains, which would lead such a viscous component. Alternatively, the site may have experienced a lightning strike, which remagnetized a large fraction of the magnetic grain spectrum. Nevertheless high coercivity components were well defined in most samples and a linear high- $T$ component was also obtained from one sample. These high coercivity and high blocking temperature components together with the data of one specimen that was fitted by a great circle, yielded a site mean palaeodirection with an acceptably small $\alpha_{95}$ as shown in Fig. 3(f). The two site mean palaeodirections from the dome and the lava flow which are considered to be of the same age are fairly close as shown in Fig. 3(e) and (f) with a difference angle of $10^{\circ}$. However, the two directions are significantly different in statistical terms, which probably suggests either a short time elapsed between the emplacement of the dome and the lava flow or that one or both sites have subsequently been disturbed.

Typical orthogonal plots of THD from a lava avalanche site (NK16) are shown in Fig. 4(a) and (b). In the former the remanence is a single component while in the latter there are two components which are sharply separated at $470^{\circ} \mathrm{C}$. Since it is difficult to distinguish the two components in the AFD data, it is suggested that this specific block rotated at $470^{\circ} \mathrm{C}$. It is noted that the cooling history of the lava avalanche site is different from block to block and a similar phenomenon was reported for a pyroclastic flow of the Unzen Volcano, Japan (Tanaka et al., 2004).

Examples of rejected orthogonal plots are shown in Fig. 4(c) and (d) for the samples of a pyroclastic flow

(NK04) and a tephra (NK17), respectively. Unstable remanences were also observed in another pyroclastic flow (NK18). The site means of these 3 sites were rejected due to a large $\alpha_{95}\left(\geq 20^{\circ}\right)$.

All site mean palaeodirections together with site statistics are summarized in Table 2 in which those of the rejected sites are indicated in a small font.

\section{Palaeointensities}

\subsection{Sample selection}

Samples for Thellier's palaeointensity experiments were selected on the basis of high stability of remanence to both AFD and THD and a rock magnetic nature less susceptible to heating. Samples were also required to show hysteresis parameters consistent with single domain (SD) or pseudo $\mathrm{SD}$ (PSD) grains.

Rock magnetic stability to heating was checked by measuring a thermomagnetic curve, i.e., a saturation magnetization versus temperature $\left(M_{\mathrm{s}}-T\right)$ curve, together with temperature dependence of magnetic susceptibility $(\chi-T$ curve). $M_{\mathrm{s}}-T$ measurements were made with a vibration sample magnetometer (Micromag 3900) of Princeton Measurements Co. in a helium atmosphere. $\chi-T$ measurements were made with a magnetic susceptibility system (MS2) of Bartington Instruments Ltd. in air. Representative $M_{\mathrm{s}}-T$ and $\chi-T$ curves are shown in Fig. 5 in which the curves are grouped according to the results of the palaeointensity experiments. In the sample selection, higher priority was given to those which show good reversibility in the heating and cooling curves both in $M_{\mathrm{s}}-T$ and $\chi-T$ measurements. Differences in the reversibility of the heating and cooling curves between successful and rejected samples are not conspicuous in Fig. 5. Nevertheless, it is recognized that successful samples showed fairly high reversibility, suggesting that they are less prone to chemical alteration by heating.

Hysteresis parameters at the room temperature were also measured with Micromag 3900. Figure 6 summarizes the hysteresis parameters in a Day plot (Day et al., 1977) with $\log -\log$ scales together with typical hysteresis curves. Open and closed circles indicate those samples which were successful and those rejected, respectively, in the palaeointensity experiments. Gray triangles show those not used in the experiments. Samples with the hysteresis parameters closer to SD nature were not necessarily higher in the success rate of the palaeointensity experiments. An exception is the basalt dyke (NK09) with SD nature in which all samples were successful in the palaeointensity experiments.

It is recognized that there are several samples in the multidomain (MD) range and a few samples lie apart from the trend of SD-MD line. An example for the latter case (NK17-1-3) is shown in Fig. 6(g). Some of these failed to give even palaeodirections as shown in Fig. 4(c, d) but others were successful at least in palaeodirections. This fact probably indicates that contributions of PSD or SD grains to the remanence varies from sample to sample even if their hysteresis characteristics are in MD range.

\subsection{Thellier's experiments}

Palaeointensity experiments using Coe's adaptation (Coe, 1967) of the Thellier method (Thellier and Thellier, 1959) were made for total of 49 samples from seven sites. 
Table 2. Site mean palaeodirections.

\begin{tabular}{lcrrrrrrr}
\hline Site & $\begin{array}{l}\text { Age } \\
\text { (Ka) }\end{array}$ & Inc & Dec & $N / n / n_{0}$ & $\alpha 95$ & $k$ & $\begin{array}{r}\text { Plat } \\
\left({ }^{\circ} \mathrm{N}\right)\end{array}$ & $\begin{array}{r}\text { Plon } \\
\left({ }^{\circ} \mathrm{E}\right)\end{array}$ \\
\hline NK09 & 1886 AD & -53.3 & 26.0 & $8 / 8 / 8$ & 4.5 & 154.6 & 68.6 & 262.8 \\
NK10 & 0.7 & -60.7 & 6.1 & $8 / 8 / 8$ & 2.1 & 693.9 & 84.2 & 305.2 \\
NK16 & $2370 \pm 70$ yBP & -64.9 & 350.1 & $5 / 6 / 6$ & 2.9 & 702.9 & 78.6 & 33.4 \\
NK02 & 5 & -62.7 & 37.0 & $7 / 7 / 7$ & 8.4 & 52.1 & 61.8 & 290.6 \\
NK04 & 7.5 & -48.2 & 348.0 & $3 / 3 / 8$ & 38.6 & 11.2 & & 60.8 \\
NK05 & 7.5 & -61.2 & 321.8 & $7 / 7 / 10$ & 4.6 & 172.1 & 66.0 \\
NK06 & 7.5 & -51.3 & 316.2 & $7 / 8 / 14$ & 4.1 & 223.6 & 54.0 & 82.6 \\
NK18 & 9 & -49.6 & 345.1 & $4 / 10 / 10$ & 21.8 & 18.7 & & \\
NK19 & 9 & -61.5 & 357.6 & $7 / 7 / 7$ & 4.0 & 226.7 & 85.1 & 17.7 \\
NK01 & 11 & -53.4 & 2.8 & $7 / 7 / 7$ & 5.3 & 128.4 & 85.2 & 205.9 \\
NK08 & 11 & -46.3 & 9.7 & $8 / 8 / 8$ & 4.7 & 141.3 & 76.6 & 217.0 \\
NK14 & 13.5 & -61.4 & 13.7 & $6 / 6 / 6$ & 5.2 & 168.7 & 78.8 & 293.1 \\
NK11 & 15 & -58.2 & 342.7 & $8 / 8 / 8$ & 4.4 & 161.8 & 76.5 & 78.3 \\
NK07 & $18 \pm 3$ & -53.7 & 359.8 & $8 / 9 / 9$ & 5.8 & 93.2 & 86.1 & 173.9 \\
NK03 & 21 & -25.2 & 20.2 & $8 / 8 / 8$ & 6.4 & 74.9 & 59.4 & 217.8 \\
NK15 & 21 & -49.6 & 352.6 & $6 / 6 / 6$ & 9.2 & 53.9 & 80.2 & 135.6 \\
NK17 & 32 & -55.6 & 349.8 & $2 / 2 / 7$ & 31.4 & 65.4 & & \\
\hline
\end{tabular}

Note:

Inc and Dec are inclination and declination of the site mean direction; $N, n$, and $n_{0}$ are numbers of samples used for site statistics, successful specimens, and total specimens used for AF and thermal demagnetizations, respectively; $\alpha_{95}$ and $k$ are a 95\% confidence circle and a precision parameter; Plat and Plon are latitude and longitude of VGP; The data indicated in a small font are those for rejected sites.

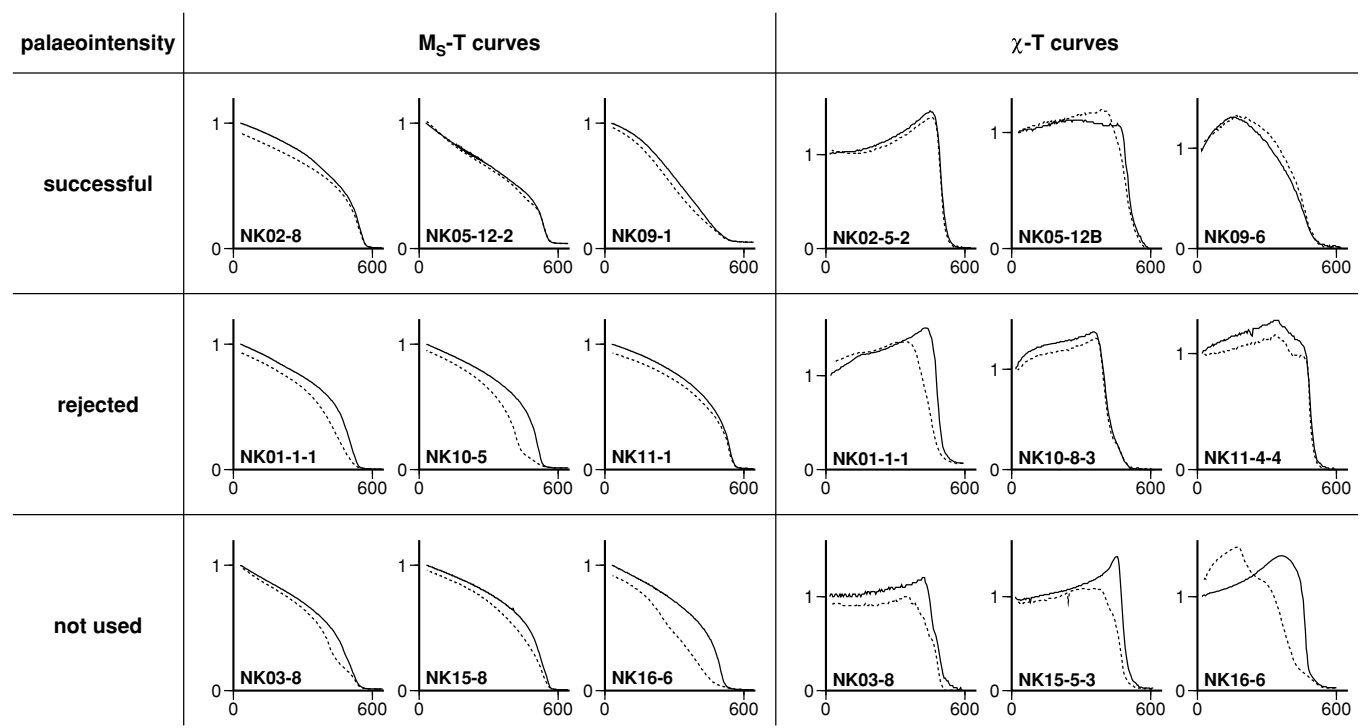

Fig. 5. Representative $M_{\mathrm{S}}-T$ and $\chi-T$ curves, arranged according to the results of the palaeointensity experiments. Solid and dotted lines indicate heating and cooling runs, respectively.

Experiments were carried out in a vacuum of $\sim 5 \mathrm{~Pa}$ and a pTRM test was included at every other step. Two series of experiments were made. In the first experiments samples from three sites showed results of low quality. These sites were omitted from the second series of experiments which concentrated on more promising samples. A moderately fair success rate of 21/49 (43\%) for specimen level was probably due to this experimental scheme.

Experimental results were analyzed using Arai plots (Nagata et al., 1963). Acceptance criteria were, (1) the linear segment should includes at least four points with a correlation coefficient $-r$ larger than 0.99 and an NRM fraction $f$ larger than $0.35,(2)$ a pTRM test is positive, as judged by a PTRM difference normalized by the length of the linear segment (DRAT) smaller than 7\%, and its accumulation over the selected temperature interval (CDRAT) smaller than $10 \%$, (3) the maximum angular deviation (MAD) of the NRM vector component corresponding to the selected linear segment is less than $7^{\circ}$ and reasonably decreases toward the origin on the orthogonal plot, which is judged by a difference angle $\alpha$ smaller than $7^{\circ}$. These criteria are similar with those proposed by Kissel and Laj (2004), but criterion (3) is more stringent. A further criterion added to (3) was that the deviation $d e v$ of Tanaka and Kobayashi (2003) 

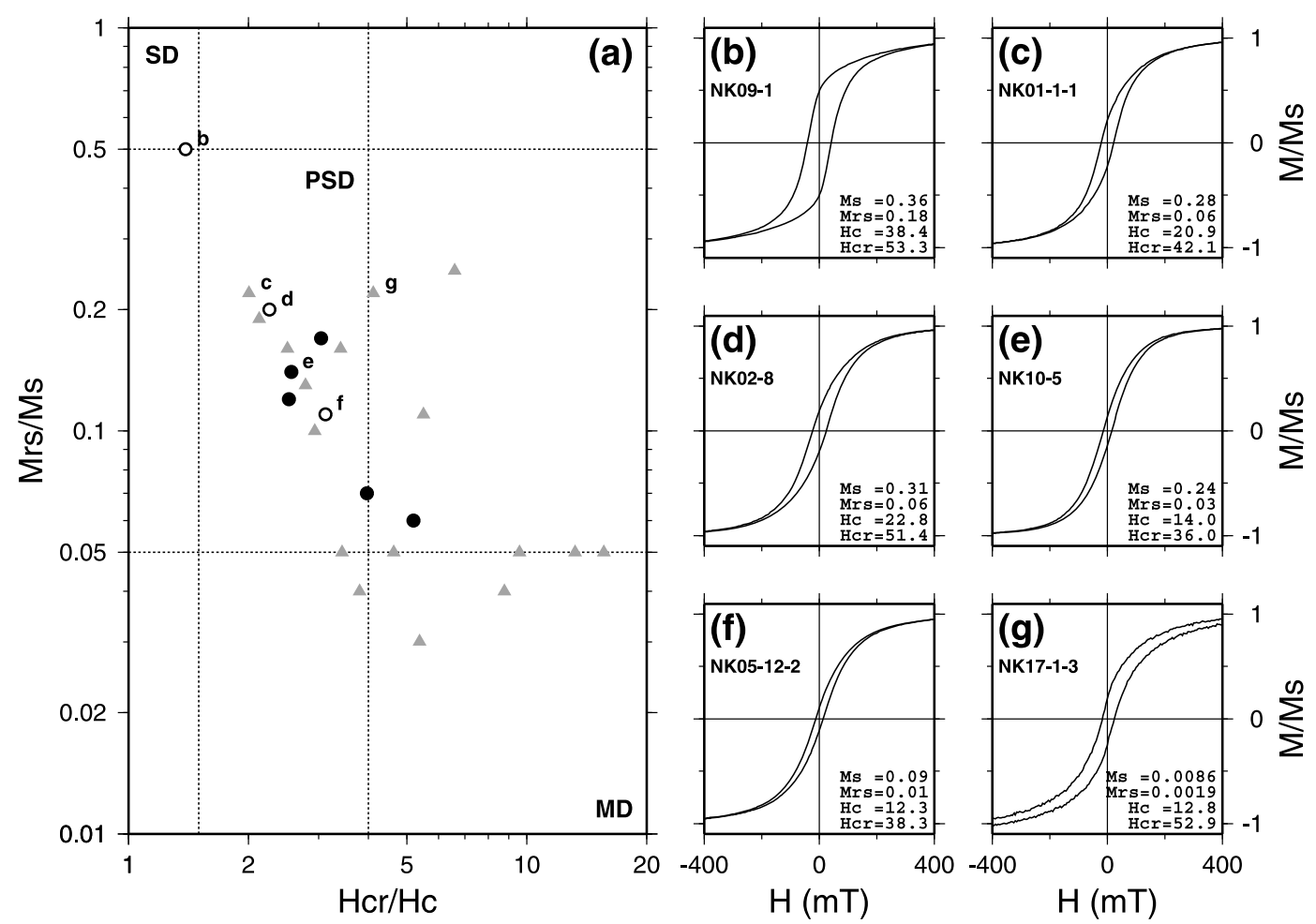

Fig. 6. Day plot of hysteresis parameters on a log-log scale (a) and representative magnetic hysteresis curves in which the slope is corrected for the effect of paramagnetism (b-g). In the Day plot (a), labels b-g correspond to the hysteresis curves (b)-(g). Open and closed circles indicate those samples which were successful and rejected, respectively, in the palaeointensity experiments. Grey triangles indicate specimens which were not used in the palaeointensity experiments. Hysteresis parameters are tabulated in each figure of (b) $-(\mathrm{g})$ where the units are Am $\mathrm{m}^{2} / \mathrm{kg}$ for saturation magnetization $\left(M_{\mathrm{s}}\right)$ and saturation remanence $\left(M_{\mathrm{rs}}\right)$ and $\mathrm{mT}$ for coercivity $\left(H_{\mathrm{c}}\right)$ and coercivity of remanence $\left(H_{\mathrm{cr}}\right)$.

should be less than $7 \%$.

Successful results were obtained from three sites: a rhyolite lava (NK02), a rhyolite dome (NK05) and a basalt dyke (NK09). Examples of successful Arai plots are shown in Fig. 7 in which two results are shown from each site.

Two results from the $5 \mathrm{Ka}$ Tapahoro rhyolite lava flow (NK02) are shown in Fig. 7(a) and (b). NK02-4-1 (a) is from the first series of experiments in which a laboratory field of $40 \mu \mathrm{T}$ was used. As the results of these first experiments indicated a palaeointensity of about $30 \mu \mathrm{T}$, the second series was carried out in a laboratory field of $30 \mu \mathrm{T}$. NK02-6-1 (b) from the second series of experiments is in good agreement with the results from NK02-4-1. In the case of NK02-6-1 (b), AFD at $20 \mathrm{mT}$ was carried out at every step. This was because there were insufficient pristine samples from this flow and we had to use samples which had previously been partially AF demagnetized for palaeodirectional measurements.

In this study, four samples were AF treated at $20 \mathrm{mT}$ for every step for the reason mentioned above. Since the first study by Coe and Grommé (1973) on the effect of AFD in the Thellier's experiments, few studies have examined this matter. In two recent studies (Riisager et al., 2002; Biggin et al., 2007), AF pre-treated specimens yielded better Arai plots, while no difference was observed in the studies of basaltic and andesitic samples by Tanaka et al. (2007a, b). For the case of the rhyolite lava and basalt dyke in this study, the Arai plots were neither improved nor worsened by the use of AFD.
Two examples of Arai plots from the 7.5 Ka rhyolite lava dome (NK05) are shown in Fig. 7(c) and (d). As discussed above, the first outcrop is thought to have suffered some movement during its cooling as shown in Fig. 3(a). Hence, samples used for the palaeointensity experiments were taken from the second outcrop. Successful results were obtained from five specimens out of ten as shown in Fig. 7(c, d). However, the specimens were actually taken from only three cores, so the final mean palaeointensity was calculated by combining the results from the same core.

Experiments on 1886 AD basalt dyke (NK09) were successful for all specimens and two examples are shown in Fig. 7(e) and (f). The excellent Arai plots obtained from these basalt samples are consistent with the hysteresis parameters, which are in SD range and $M_{\mathrm{S}}-T$ and $\chi-T$ curves which indicate almost no chemical alteration (see Figs. 5 and 6).

In spite of high quality of the NK09 results, it is noted that there is significant dispersion between the palaeointensities obtained. The values range from 54.1 to $74.7 \mu \mathrm{T}$, and the mean of specimen palaeointensities is $64.3 \pm 6.7 \mu \mathrm{T}$ $(n=10)$, indicating a standard deviation of $10.4 \%$. This is not unusual because a large dispersion of palaeointensities from a single lava flow has often been reported (e.g., Böhnel et al., 2003; Alva-Valdivia, 2005). Nevertheless, it might indicate an intrinsic limitation of the Thellier's experiments that a large dispersion is observed from such excellent materials.

The site mean palaeointensity for NK09, calculated on 

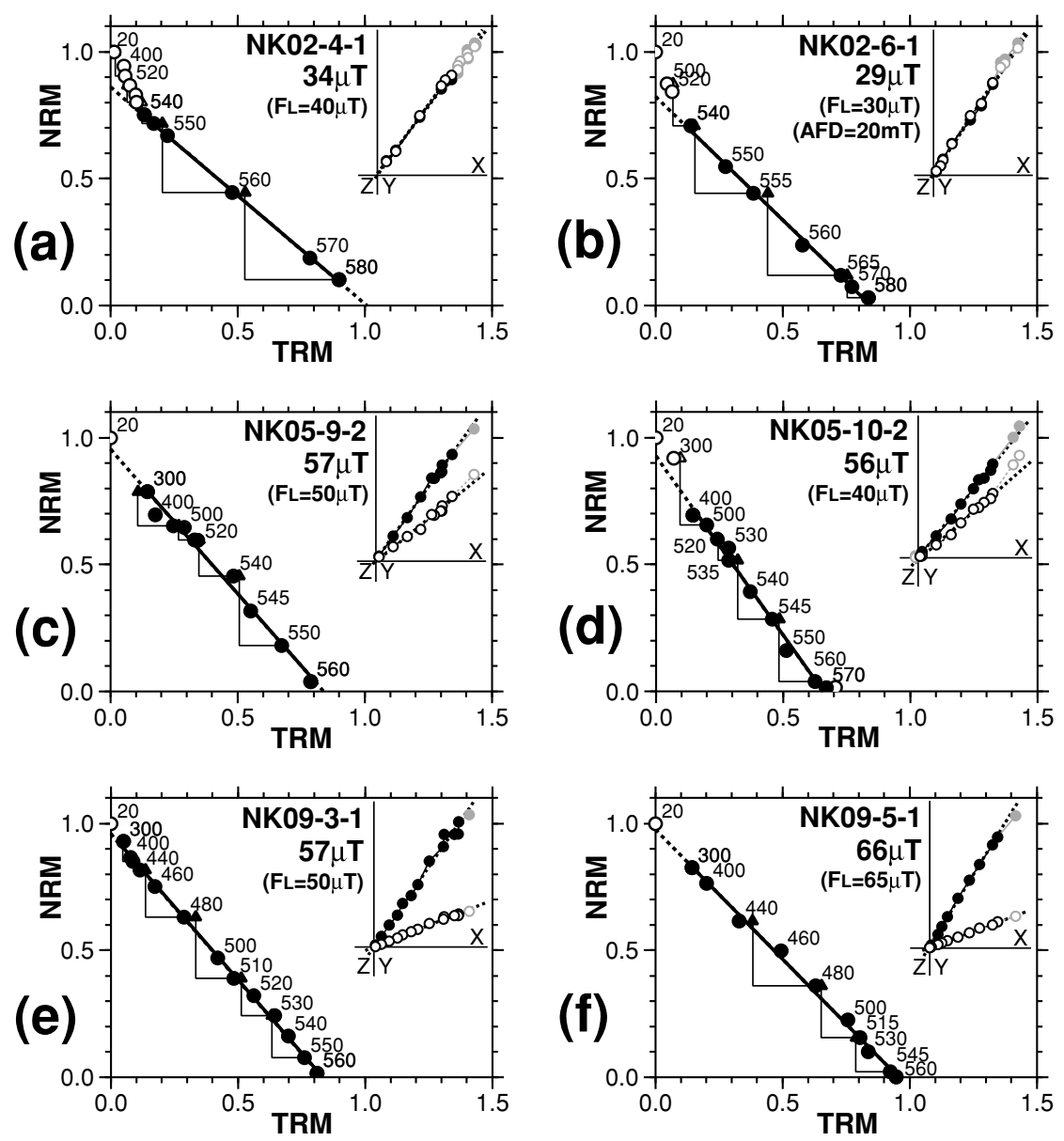

Fig. 7. Examples of successful Arai plots. Closed and open circles indicate those data points which were included and excluded, respectively, in the linear segment. Closed and open triangles indicate pTRM tests which were judged to be positive and negative, respectively. Insets indicate orthogonal plots of remanence vectors for the NRM steps shown in a sample coordinate system in which $-Z$ is the direction of the laboratory field.

the basis of independent samples, is $62.9 \pm 5.7 \mu \mathrm{T}(N=6)$. This site mean palaeointensity may also be slightly biased towards a high value. The actual field intensity at the site for $1886 \mathrm{AD}$ is unknown, however the mean palaeointensity is some $11 \%$ larger than the total field of $56.5 \mu \mathrm{T}$ calculated from the IGRF1900 (IAGA WG, 2005). The field intensity over the region has decreased by about $2 \mu \mathrm{T}$, or $4 \%$ over the past century, in accord with a general decrease in global dipole moment. A drop of as much as $11 \%$ in the 15 year period from 1886 to 1900 is therefore considered unlikely, and the mean palaeointensity value of $62.9 \mu \mathrm{T}$ is therefore probably too high.

This might be an indication of the experimental problems of the Thellier's method which has been frequently discussed in the literature (e.g., Tanaka and Kono, 1991; Calvo et al., 2002; Yamamoto et al., 2003).

The site mean palaeointensities together with corresponding values of the VDM and VADM are summarized in Table 3. Details of the specimen level results including the quality factors of Coe et al. (1978) are summarized in Appendix for 21 successful specimens.

Examples of rejected Arai plots are shown in Fig. 8. A negative pTRM test was the most frequent reason for the failure of an experiment. The Arai plots shown in Fig. 8(a) and (b) were rejected because the DRAT was larger than $7 \%$ in each case.

The Arai plot shown in Fig. 8(c) was rejected due, not only to negative pTRM test, but also poor linearity, with the correlation coefficient below 0.99 . The magnetic susceptibility, measured after every step, also increased markedly above $400^{\circ} \mathrm{C}$, as shown in the inset. In this study change in magnetic susceptibility was not used as a quantitative criterion. In most specimens the change was between $5 \%$ and $20 \%$; however, the increase of about $40 \%$ observed in this specimen was taken to indicate that significant alteration to the magnetic mineralogy had occurred during heating.

Arai plots with two linear segments as shown in Fig. 8(d) are also one of the most frequent reasons for rejection. In the case of NK11-6-3, the pTRM test was positive for both segments, making it difficult to decide which of them should be adopted. In the past, the low- $T$ segment was often adopted by supposing that chemical alteration of magnetic minerals occurred in the high- $T$ range. Valet (2003) argued that such data should be rejected: either because of an effect of MD grains on the steep slope of the low- $T$ segment, or because of chemical alteration even at these relatively low temperatures. In the case of Fig. 8(d) we suspect chemical alteration to be the cause because both segments show a high degree of linearity, in contrast to the concave-up trend often recognized in data from MD grains. 

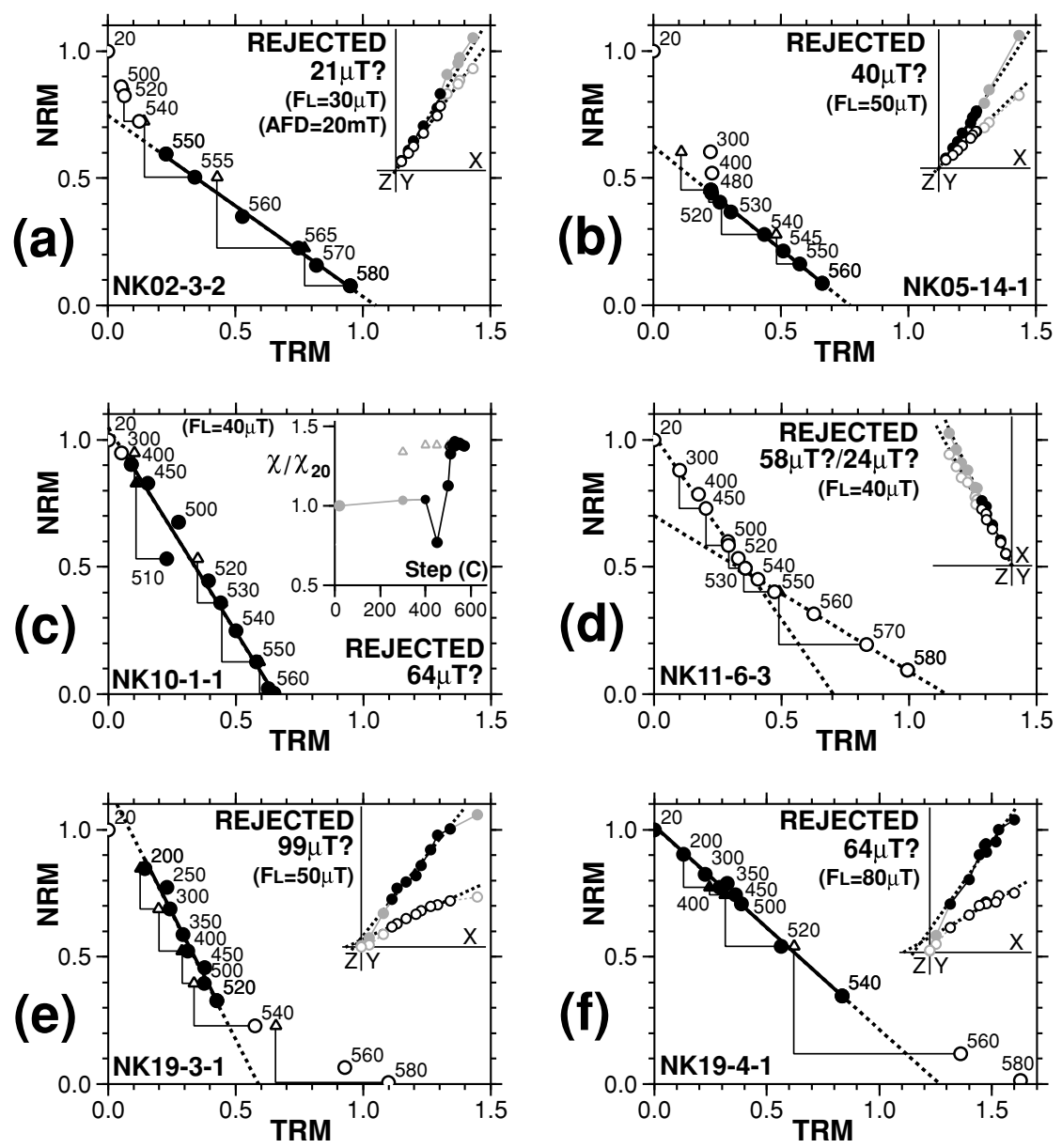

Fig. 8. Examples of rejected Arai plots. Notations are as for Fig. 7 except for (c) in which the change in magnetic susceptibility, $\chi$, measured after each step is shown in the inset.

Table 3. Site mean palaeointensities.

\begin{tabular}{lclcrr}
\hline Site & $\begin{array}{c}\text { Age } \\
(\mathrm{Ka})\end{array}$ & $N\left(n / n_{0}\right)$ & $\begin{array}{c}F \\
(\mu \mathrm{T})\end{array}$ & \multicolumn{2}{c}{ VDM } \\
& \multicolumn{1}{c}{$\left(10^{22} \mathrm{Am}^{2}\right)$} \\
\hline NK09 & $1886 \mathrm{AD}$ & $6(10 / 10)$ & $62.9 \pm 5.7$ & $11.7 \pm 1.1$ & $11.1 \pm 1.0$ \\
NK02 & 5 & $5(6 / 9)$ & $31.0 \pm 3.5$ & $5.1 \pm 0.6$ & $5.5 \pm 0.6$ \\
NK05 & 7.5 & $3(5 / 10)$ & $58.1 \pm 2.9$ & $9.8 \pm 0.5$ & $10.3 \pm 0.5$ \\
\hline
\end{tabular}

Note:

$N$, number of samples used for the site mean; $n / n_{0}$, numbers of successful/total specimens; $F$, simple average of sample palaeointensities and its standard deviation.

Two examples from the $9 \mathrm{Ka}$ rhyolitic Rotoma lava flow are shown in Fig. 8(e) and (f). NK19-3-1 (e) was rejected due to a negative pTRM test together with a large value of their accumulation (CDRAT $>10 \%$ ). NK19-4-1 (f) passed the pTRM test criteria in terms of DRAT and CDRAT, but failed criterion (3), that the NRM vector should decrease toward the origin. In the orthogonal plot of zero step NRM vectors shown in the inset, the NRM vector can be seen to deviate toward the $-Z$ axis, which is the direction of the laboratory field. For this specimen, $\alpha$ and $d e v$ were $7.3^{\circ}$ and $9.2 \%$, respectively.

\section{Discussion}

In Fig. 9 the new palaeomagnetic data obtained in this study, shown in large red circles with error bars, are com- pared with previously reported data from New Zealand and eastern Australia for the past $21 \mathrm{Ka}$. Since all the previous data, except for two, were retrieved from the data compilation by Korte et al. (2005) in which the ages are in calibrated calendar years BP (cal. yr. BP), the C-14 ages were converted using the program CALIB of Stuiver and Reimer (1993) Version 5.0.

Australian archaeomagnetic and archaeointensity data (Barbetti, 1977, 1983) were taken from AUS and AUI of the Korte et al. (2005) data compilation and are shown in small orange circles in the figure. Two volcanic data from New Zealand (Tanaka et al., 1994) were taken from the original paper and are shown with the same symbols. Cox (1969), in his early study of palaeosecular variation in New Zealand, sampled two sites which would be relevant to the 


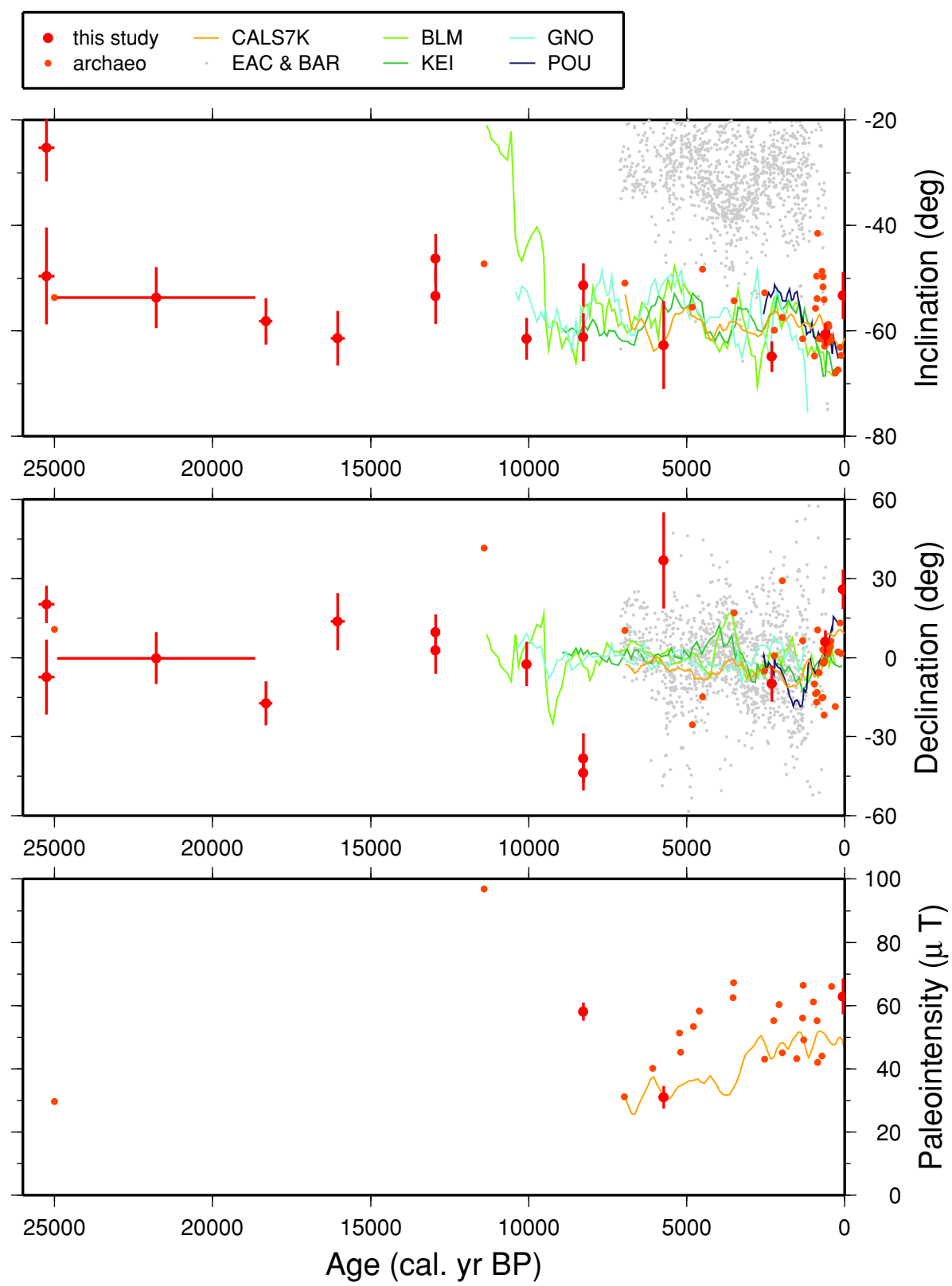

Fig. 9. Palaeosecular variations for the last $21 \mathrm{Ka}$ in New Zealand and eastern Australia. The ages are shown in calibrated calendar years BP, which were converted from C-14 ages of Nairn (2002) with uncertainties of \pm 100 years using the program CALIB of Stuiver and Reimer (1993) Version 5.0. New data from this study are shown by large red circles with error bars. Small red circles are archaeomagnetic data from Australia together with two volcanic data from New Zealand. Lake sediments data are from Lake Pounui (POU), New Zealand and five lakes in eastern Australia (EAC, BAR, BLM, KEI, GNO). The palaeosecular variation curves are shown in colored lines except for EAC and BAR which are shown in discrete grey dots. Model predictions for New Zealand from CALS7K are shown in orange lines.

present study. However Cox quoted only NRM directions; he did not use any partial or progressive demagnetization to check for or remove secondary components of magnetization. Cox's results are therefore not included.

A palaeosecular variation record for the past 2500 years, compiled from the sediments of Lake Pounui, New Zealand was reported by Turner and Lillis (1994). In Fig. 9 this palaeosecular variation curve is shown in dark blue line: the data were taken from POU of Korte data compilation.

Palaeosecular variation curves from eastern Australian lake sediments are available for Lake Eacham (EAC) and Lake Barrine (BAR) (Constable and McElhinny, 1985), Lake Bullenmerri (BLM), Lake Keilambete (KEI), and
Lake Gnotuk (GNO) (Barton and McElhinny, 1981). All data were taken from the Korte data compilation. In Fig. 9 the secular variation curves are shown in light green (BLM), dark green (KEI), and aquamarine (GNO). Many discrete data from EAC and BAR are shown in grey dots.

In Fig. 9, it is clear that, with the exceptions of the EAC and BAR data, the palaeosecular variation curves from lake sediments are in good agreement with each other. Inclinations from EAC and BAR are lower than other records, which is obviously due to their low site latitude $\left(17^{\circ} \mathrm{S}\right) \mathrm{com}-$ pared to those of other sites $\left(38^{\circ} \mathrm{S}\right.$ and $\left.41^{\circ} \mathrm{S}\right)$. In fact, all data become scattered around the center when the palaeodirections are viewed relative to the axial geocentric dipole field 

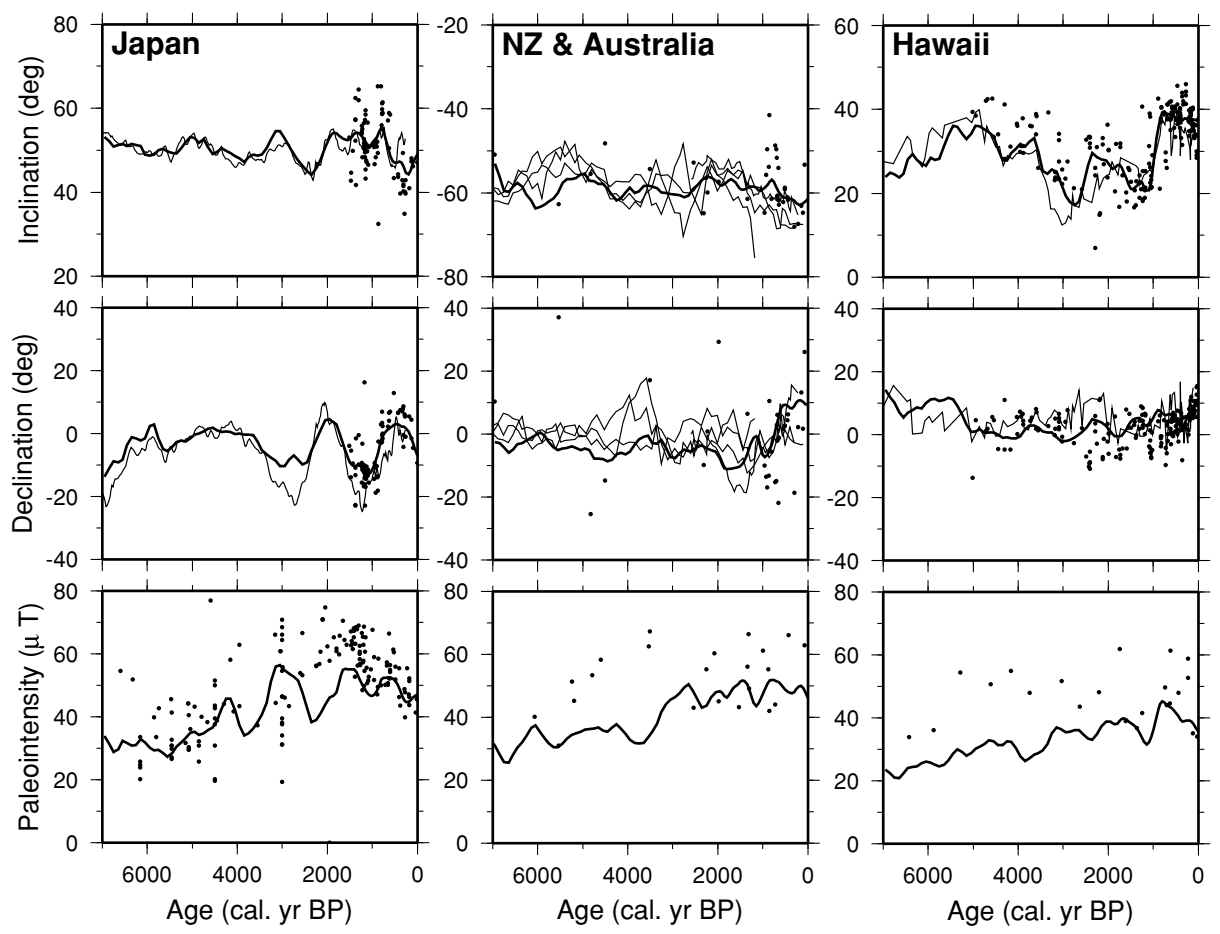

Fig. 10. Palaeosecular variation in the wider Pacific region for the last 7000 years, compared with CALS7K predictions which are shown in thick solid lines. Thin lines and small solid circles indicate sedimentary records and volcanic data including archaeomagnetism, respectively, which are retrieved from the data compilation of Korte et al. (2005). Poor fit of the model to the New Zealand and Australia palaeointensity data is also evident in Hawaii, while better agreement is observed in Japan.

direction of the site, so called Inc' and Dec' (or IT and DT), which was first introduced by Turner and Thompson (1981) to compare secular variation records from different latitudes and used by Hoffman (1984) to view transitional records. It should be noted, however, that the declination values of EAC and BAR by Korte et al. (2005) were presented as those of adjusted, because the sediment cores were not oriented azimuthally. Due to their large scatter, the sedimentary records of EAC and BAR are not further considered. It is also recognized from Fig. 9 that there is little difference between the palaeosecular variation curves from New Zealand (POU) and the other eastern Australian sites despite the $30^{\circ}$ difference in site longitude $\left(175^{\circ} \mathrm{E}\right.$ vs. $\left.143^{\circ} \mathrm{E}\right)$.

The inclinations of the archaeomagnetic and volcanic data for the last ten thousand years, including those in this study, are in fairly good agreement with the sedimentary records. On the other hand, the declinations from the former are not in good agreement with those from the sediments: two of the declinations from this study show particularly large differences. This does not necessarily indicate that the archaeo and volcanic data are less reliable. Some differences might be expected between the archaeo/volcanic data and the lake sediments data because the former are discrete, instantaneous recordings of the palaeomagnetic field, while the latter include a certain amount of filtering, or smoothing, even for lake sediments with high sedimentation rates.

In Fig. 9, model predictions from CALS7K (Korte and Constable, 2005) at $\left(38.0^{\circ} \mathrm{S}, 176.5^{\circ} \mathrm{E}\right)$ are shown in orange lines. It is recognized that the lake sediments data show very good agreement with the model predictions especially in inclination curves. This must be the result of modelling
CALS7K in which larger weight must have been given to the lake sediments data although any subjective judgments were not involved in the analysis by Korte and Constable (2005). On the other hand, the archaeo and volcanic palaeointensities show quite large discrepancies from the model prediction. This fact is puzzling because these archaeo and volcanic data (AUI) are the only palaeointensity data from the Australian region used in the analysis of Korte and Constable (2005).

On the other hand, the palaeointensity obtained from site NK02, Tapahoro lava flow, dated at 5730 cal. yr. BP is in good agreement with the model. The palaeointensity from site NK05, Hainini lava dome, dated at $8270 \mathrm{cal}$. yr. BP, is also concordant with the world-wide trend in which there is a moderate high at 7-8 Ka (Yang et al., 2000). As discussed in the previous section, the sample mean palaeointensity of NK09, the 1886 AD Tarawera basalt dyke, is some 11\% larger than the expected value, suggesting a possible bias.

Relatively poor fit of the volcanic palaeointensity data with CALS7K model values is observed over the wider Pacific region. In Fig. 10 we show the data complied by Korte et al. (2005) compared with the CALS7K model for the three areas of Japan, New Zealand and Australia and Hawaii. The CALS7K curves were calculated at three representative locations, $\left(35^{\circ} \mathrm{N}, 136^{\circ} \mathrm{E}\right),\left(38^{\circ} \mathrm{S}, 176.5^{\circ} \mathrm{E}\right)$, $\left(19.5^{\circ} \mathrm{N}, 155.5^{\circ} \mathrm{W}\right)$, and are shown as thick solid lines. Thin lines and small dots indicate sedimentary records and volcanic (including archaeomagnetic) data respectively, also from the data compilation of Korte et al. (2005).

Very good agreement is recognized between the palaeodirection data and the CALS7K curves for all three 


\section{Appendix. Specimen palaeointensity results}

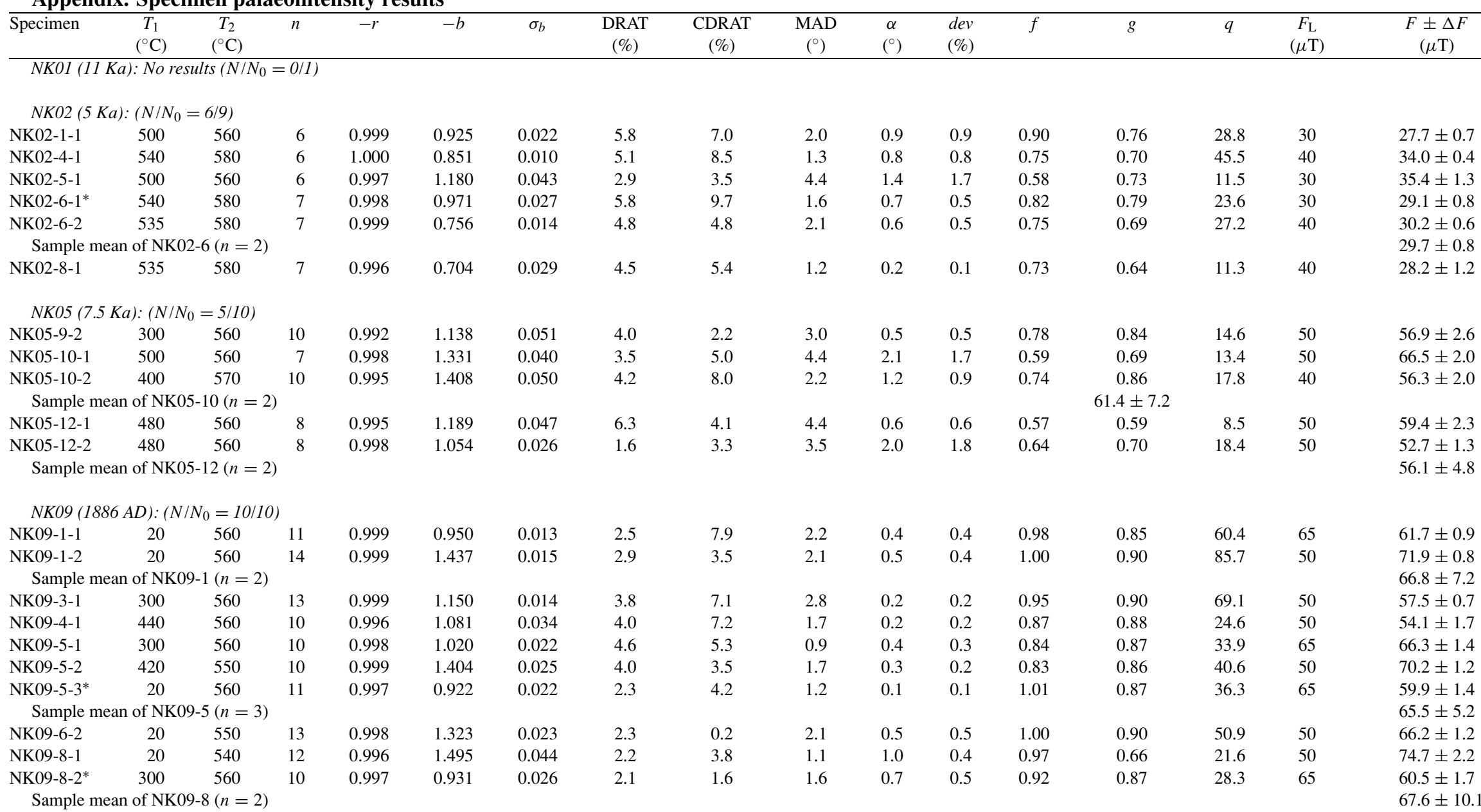

NK10 (0.7 Ka): No results $\left(N / N_{0}=0 / 3\right)$

NK11 (15 Ka): No results $\left(N / N_{0}=0 / 4\right)$

NK19 $(9 \mathrm{Ka})$ : No results $\left(N / N_{0}=0 / 12\right)$ Note:

$T_{1}, T_{2}$, lower and upper temperatures for the linear segment; $n$, number of data point included in the linear regression; $r$, correlation coefficient of the linear segment; $b$, slope of the segment; $\sigma_{b}$, standard error of $b$; DRAT, CDRAT, maximum PTRM difference over the linear segment and their accumulation; MAD, maximum angular deviation of the NRM vector corresponding to the linear segment; $\theta$, dev, difference angle and deviation of the selected NRM component from the origin on the orthogonal plot; $f, g, q$, quality parameters after Coe $e t a l$. (1978); $F_{\mathrm{L}}$, laboratory field strength; $F, \Delta F$, palaeointensity and its standard error; $(*)$, the experiment included AFD with $20 \mathrm{mT}$ for all steps. 
areas, although the volcanic data show significant scatter. On the other hand the poor fit of CALS7K to the New Zealand and Australia palaeointensity data is also evident in Hawaii, while better agreement is observed in Japan. It is difficult to identify the reason for this disagreement; whether it is due to the sparcity of data or other deficiencies in the modelling process, a general bias of palaeointensity determinations to high values, or some anomalous feature of the geomagnetic field in the Pacific region. Future modelling, with more reliable palaeointensity data is necessary in order to solve the problem.

The new palaeointensity data presented in this study, though a small contribution, meet the most stringent recently adopted criteria for palaeointensity determination and will form an important addition to the southern hemisphere millennial scale palaeosecular variation record.

\section{Conclusions}

Samples from the Okataina Volcanic Centre, New Zealand, comprising rhyolitic lavas, pyroclastics and one basalt dyke, showed a wide range of magnetic hysteresis properties on the Day plot. Most of the flows, including some lavas with MD property, showed high stability of remanences. Exceptions were two pyroclastics and one tephra with MD natures in which the remanences were unstable. Rejecting these three sites, 14 reliable palaeodirections were obtained for $0.1-21 \mathrm{Ka}$. Of the 7 flows showing the highest stability of remanence and SD to PSD rock magnetic properties, only 3 yielded successful results in the Thellier's palaeointensity experiments. The new data together with other archaeo- and volcanic data from New Zealand and eastern Australia were compared with those from lake sediments for the last $10 \mathrm{kyr}$. Agreement between the two datasets was good in inclination but not so good in declination. Although the sedimentary records show an excellent agreement with the model predictions from CALS7K, disagreement of palaeointensity data with the model was observed for the larger Pacific region. This indicates the importance of further additional reliable palaeointensity data. The 14 new palaeodirections together with 3 palaeointensities of this study make a small, southern hemisphere contribution to the worldwide database of palaeosecular variation.

Acknowledgments. Sample collection for this study was made as a part of the Japan and New Zealand joint research which was carried out during 1990-1991. Measurements and publications have long been finished for the Taupo samples (Geophys. J. Int., 124, 919-934, 1996) and the Ruapehu samples (J. Geomag. Geoelectr., 49, 587-599, 1997). Prolonged delay in the measurements of the Okataina samples which should have been finished a decade ago is all due to HT's slow work. There are several people we would like to thank. First we express our gratitude to Ian Nairn. Without his guide and suggestions in the field, this project did not exit. Next, we acknowledge various help in the project given by Masaru Kono, Hideo Tsunakawa, Yoshiyuki Tatsumi, and Bruce Houghton. We also thank Kazuto Kodama for use of the rock magnetic facilities at the Center for Advanced Marine Core Research, Kochi University. Expert comments given by Andrei Kosterov and an anonymous reviewer, which improved the original manuscript, are much appreciated.

\section{References}

Alva-Valdivia, L. M., Comprehensive paleomagnetic study of a succession of Holocene olivine-basalt flow: Xitle Volcano (Mexico) revisited, Earth Planets Space, 57, 839-853, 2005.

Barbetti, M., Measurements of recent geomagnetic secular variation in Southeastren Australia and the question of dipole wobble, Earth Planet. Sci. Lett., 36, 207-218, 1977.

Barbetti, M., Archeomagnetic results from Australia, in Geomagnetism of Baked Clays and Recent Sediments, edited by Creer, K. M., P. Tucholka, and C. E. Barton, 324 pp., Elsevier, Amsterdam, 1983.

Barton, C. E. and M. W. McElhinny, A 10000 yr geomagnetic secular variation record from three Australian maars, Geophys. J. R. Astr. Soc., 67, 465-485, 1981.

Biggin, A. J., M. Perrin, and J. Shaw, A comparison of a quasiperpendicular method of absolute paleointensity determinatin with other thermal and microwave techniques, Earth Planet. Sci. Lett., 257, 564 581, 2007.

Böhnel, H., A. J. Biggin, D. Walton, J. Shaw, and J. A. Share, Microwave paleointensities from a recent Mexican lava flow, baked sediments and reheated pottery, Earth Planet. Sci. Lett., 214, 221-236, 2003.

Calvo, M., M. Prévot, M. Perrin, and J. Riisager, Investigating the reasons for the failure of palaeointensity experiments: a study on historical lava flows from Mt. Etna (Italy), Geophys. J. Int., 149, 44-63, 2002.

Coe, R. S., Paleo-intensity of the earth's magnetic field determined from Tertiary and Quaternary rocks, J. Geophys. Res., 72, 3247-3262, 1967.

Coe, R. S. and C. S. Grommé, A comparison of three methods of determining geomagnetic paleointensities, J. Geomag. Geoelectr., 25, 415-435, 1973

Coe, R. S., S. Grommé, and E. A. Mankinen, Geomagnetic paleointensities from radiocarbon-dated lava flows on Hawaii and the question of the Pacific nondipole low, J. Geophys. Res., 83, 1740-1756, 1978.

Constable, C. G. and M. W. McElhinny, Holocene geomagnetic secular variation records from north-eastern Australian lake sediments, Geophys. J. R. Astr. Soc., 81, 121-130, 1985.

Cox, A., A paleomagnetic study of secular variation in New Zealand, Earth Planet. Sci. Lett., 6, 257-267, 1969.

Creer, K. M., P. Tucholka, and C. E. Barton (eds.), Geomagnetism of Baked Clays and Recent Sediments, 324 pp., Elsevier, Amsterdam, 1983.

Daly, L. and M. Le Goff, An updated and homogeneous world secular variation data base. 1. smoothing of the archaeomagnetic results, Phys. Earth Planet. Inter., 93, 159-190, 1996.

Day, R., M. Fuller, and V. A. Schmidt, Hysteresis properties of titanomagnetites: grain-size and compositional dependence, Phys. Earth Planet. Inter., 13, 260-267, 1977.

Froggatt, P. C. and D. J. Lowe, A review of late Quaternary silicic and some other tephra formations from New Zealand: their stratigraphy, nomenclature, distribution, volume, and age, New Zealand J. Geol. Geophys., 33, 89-109, 1990

Hoffman, K. A., A method for the display and analysis of transitional paleomagnetic data, J. Geophys. Res., 89, 681-684, 1984.

Hongre, L., G. Hulot, and A. Khokhlov, An analysis of the geomagnetic field over the past 2000 years, Phys. Earth Planet. Inter., 106, 311-335, 1998.

International Association of Geomagnetism, Aeronomy (IAGA), Division V, Working Group VMOD: Geomagnetic Field Modeling, The 10th generation international geomagnetic reference field, Geophys. J. Int., 161, 561-565, 2005.

Kinoshita, H., List of archeomagnetic and paleomagnetic results, J. Geomag. Geoelectr., 22, 507-550, 1970.

Kissel, C. and C. Laj, Improvements in procedure and paleointensity selection criteria (PICRIT-03) for Thellier and Thellier determinations: application to Hawaiian basaltic long cores, Phys. Earth Planet. Inter., 147, 155-169, 2004.

Korte, M. and C. G. Constable, Continuous geomagnetic field models for the past 7 millennia: 2. CALS7K, Geochem. Geophys. Geosyst., 6, 2004GC000801, 2005.

Korte, M., A. Genevey, C. G. Constable, U. Frank, and E. Schnepp, Continuous geomagnetic field models for the past 7 millennia: 1 . A new global data compilation, Geochem. Geophys. Geosyst., 6, 2004GC000800, 2005.

Kovacheva, M., Updated archaeomagnetic results from Bulgaria: the last 2000 years, Archaeomagnetic database from Bulgaria: the last 8000 years, Phys. Earth Planet. Inter., 70, 219-223, 1992.

McElhinny, M. W. and W. E. Senanayake, Variations in the geomagnetic dipole 1: The past 50000 years, J. Geomag. Geoelectr., 34, 39-51, 1982. 
Nagata, T., Y. Arai, and K. Momose, Secular variation of the geomagnetic total force during the last 5000 years, J. Geophys. Res., 68, 5277-5281, 1963.

Nairn, I. A., Geology of the Okataina Volcanic Centre, Scale 1:50000, Geology of the Okataina Volcanic Centre, Scale 1:50000, pp.156, Lower Hutt, New Zealand, 2002.

Ohno, M. and Y. Hamano, Global Analysis of geomagnetic field: time variation of the dipole moment and the geomagnetic pole in the Holocene, J. Geomag. Geoelectr., 45, 1455-1466, 1993.

Riisager, P., J. Riisager, N. Abrahamsen, and R. Waagstein, Thellier palaeointensity experiments on Faroes flood basalts: technical aspects and geomagnetic implications, Phys. Earth Planet. Inter., 131, 91-100, 2002.

Sternberg, R. S., W. L. Deaver, E. A. Kuter, and A. L. Kiley, A north American archaeomagnetic database, J. Geomag. Geoelectr., 49, 519522, 1997.

Stuiver, M. and P. J. Reimer, Extended 14C database and revised CALIB radiocarbon calibration program, Radiocarbon, 35, 215-230, 1993.

Tanaka, H. and M. Kono, Preliminary results and reliability of palaeointensity studies on historical and ${ }^{14} \mathrm{C}$ dated Hawaiian lavas, J. Geomag. Geoelectr., 43, 375-388, 1991.

Tanaka, H. and T. Kobayashi, Paleomagnetism of the late Quaternary Ontake Volcano, Japan: directions, intensities, and excursions, Earth Planets Space, 55, 189-202, 2003.

Tanaka, H., A. Otsuka, T. Tachibana, and M. Kono, Paleointensities for 10-22 ka from volcanic rocks in Japan and New Zealand, Earth Planet. Sci. Lett., 122, 29-42, 1994.

Tanaka, H., G. M. Turner, B. F. Houghton, T. Tachibana, M. Kono, and M. O. McWilliams, Palaeomagnetism and chronology of the central Taupo Volcanic Zone, New Zealand, Geophys. J. Int., 124, 919-934, 1996.
Tanaka, H., H. Hoshizumi, Y. Iwasaki, and H. Shibuya, Applications of paleomagnetism in the volcanic field: A case study of the Unzen Volcano, Japan, Earth Planets Space, 56, 635-647, 2004.

Tanaka, H., R. Kamizaki, and Y. Yamamoto, Palaeomagnetism of the Older Ontake Volcano, Japan: contributions to the palaeosecular variation for 750-400 Ka, the lower half of the Brunhes Chron, Geophys. J. Int., 169, 81-90, 2007a.

Tanaka, H., N. Takahashi, and Z. Zheng, Paleointensities from Tertiary basalts, Inner Mongolia and Hebei Province, northeastern China, Earth Planets Space, 59, 747-754, 2007b.

Thellier, E. and O. Thellier, Sur l'intensité du champ magnetique terrestre dans le passé historique et géologique, Ann. Geophys., 15, 285-376, 1959.

Turner, G. M. and R. Thompson, Lake sediment record of the geomagnetic secular variation in Britain during Holocene times, Geophys. J. R. Astr. Soc., 65, 703-725, 1981.

Turner, G. M. and D. A. Lillis, A palaeomagnetic secular variation record for New Zealand during the past 2500 years, Phys. Earth Planet. Inter., 83, 265-282, 1994.

Valet, J.-P., Time variations in geomagnetic intensity, Rev. Geophys., 41, doi:10.1029/2001RG000104, 2003.

Yamamoto, Y., H. Tsunakawa, and H. Shibuya, Paleointensity study of the Hawaiian 1960 lava: implications for possible causes of erroneously high intensities, Geophys. J. Int., 153, 263-276, 2003.

Yang, S., H. Odah, and J. Shaw, Variations in the geomagnetic dipole moment over the last 12000 years, Geophys. J. Int., 140, 158-162, 2000.

H. Tanaka (e-mail: htanaka@kochi-u.ac.jp), N. Komuro, and G. M. Turner 